
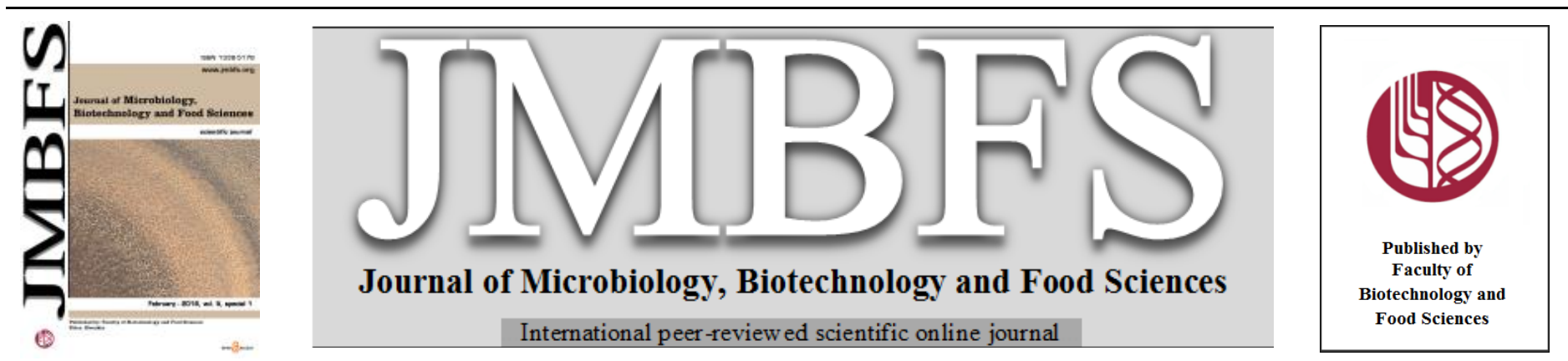

\title{
COMPARISON OF TWO COLORIMETRIC ANTIOXIDANT CAPACITY ASSESSMENT METHODS IN BOVINE SEMEN FRACTIONS
}

\author{
Eva Tvrdá $*^{l}$, Monika Schneidgenová ${ }^{1}$, Tomáš Jambor $^{1}$, Dušan Pá́l ${ }^{2}$, Csaba Szabó ${ }^{3}$, Norbert Lukác ${ }^{l}$
}

Address(es): MSc. Eva Tvrdá, PhD.,

${ }^{1}$ Slovak University of Agriculture in Nitra, Faculty of Biotechnology and Food Sciences, Department of Animal Physiology, Tr. A. Hlinku 2, 949 76 Nitra, Slovakia, +421-37-641-4288.

${ }^{2}$ Constantine the Philosopher University in Nitra, Faculty of Natural Sciences, Department of Botany and Genetics, Nábrežie mládeže 91 , 94974 Nitra, Slovakia.

${ }^{3}$ Szent István University, Faculty of Agricultural and Environmental Sciences, Department of Animal Physiology and Health, Páter Károly utca 1, 2100 Gödöllö, Hungary.

*Corresponding author: evina.tvrda@gmail.com

doi: 10.15414/jmbfs.2016.5.special1.47-49

\section{ARTICLE INFO}

Received 26. 12. 2015

Revised 19. 1.2016

Accepted 30. 1. 2016

Published 8. 2. 2016

Regular article

open $\bigodot_{\text {ACCESS }}$

\begin{abstract}
The antioxidant capacity represents the concentration and activity of diverse components which prevent oxidative damage to biomolecules. This study compares the effectiveness two routinely available protocols (Total antioxidant status - TAS and Ferric reducing ability of plasma - FRAP) with respect to the relationship between the antioxidant capacity and semen quality in bovine seminal plasma and spermatozoa. Computer assisted semen analysis was used to evaluate selected spermatozoa motion parameters; TAS and FRAP were assessed using UV/VIS spectrophotometry. Higher antioxidant activity $(\mathrm{P}<0.01)$ measured by both techniques was recorded in the seminal plasma. At the same time, the antioxidant properties evaluated by both techniques significantly $(\mathrm{P}<0.01)$ reflected on the semen quality in both seminal plasma as well as spermatozoa. Our results suggest that both methodologies used to assess the antioxidant capacity of semen are equally suitable to be routinely used in veterinary medicine.
\end{abstract}

\section{INTRODUCTION}

Literally every ejaculate is ought to be contaminated with potential sources of reactive oxygen species (ROS) (Aitken, 1995), high concentration of which has been associated with a decreased motility (Eskenazi $\boldsymbol{e t}$ al., 2003) and efficacy of sperm-oocyte fusion (Agarwal et al., 2007), increased DNA damage (Armstrong et al., 1999) as well as cellular membrane lipid peroxidation (Aitken, 1995) in the male gamete.

Because ROS have both physiological and pathological properties, the organism has developed specific defence mechanisms to maintain the ROS levels within a physiological range. Antioxidants are therefore compounds that dispose, scavenge and inhibit the formation of ROS, or oppose their actions (Sikka et al., 1995). Due to the small volume of cytoplasm and low concentrations of scavenging enzymes, spermatozoa have limited antioxidant protection. Meanwhile, the seminal plasma has been repeatedly defined as an important protector against possible ROS formation or distribution, due to a vast array of both enzymatic as well as non-enzymatic antioxidants (Agarwal et al., 2006).

The chemical diversity of antioxidants makes it difficult to separate, detect or quantify individual antioxidants from a complex biological sample. Therefore, the total antioxidant capacity is often useful to evaluate the general beneficial properties of the sample based on the cooperative action of individual antioxidant compounds (Apak et al., 2013).

Several assays have been proposed to estimate the antioxidant capacity in animal reproductive cells and tissues, including 2,2-azinobis (3-ethyl-benzothiazoline-6sulfonic acid) (ABTS) (Badarinath et al., 2010), 2,2-diphenyl-1-picrylhydrazyl (DPPH) (Alam et al., 2002), ferric reducing antioxidant power (FRAP) (Benzie and Strain, 1999) or the oxygen radical absorption capacity (ORAC) (Prior $\boldsymbol{e t}$ al., 2003). According to Alam et al. (2013), ABTS-based colorimetric assays and FRAP are the most common methods applied in animal research.

Therefore the aim of this study was to compare the effectiveness of antioxidant capacity determination in bovine seminal plasma and spermatozoa by two popular spectrophotometric tests: ABTS and FRAP. Both methods were validated statistically, and their effectiveness was compared with regard to the most significant spermatozoa motility characteristics.

\section{MATERIAL AND METHODS}

Semen samples were collected in duplicates from 37 Simmental-Fleckvieh bulls kept in the Breeding Centre of the Slovak Biological Services, Nitra, Slovakia. The animals were 4-6 years old and fed a standard diet consisting of green and cereal fodder, berseem, straw and commercial mixtures for beef cattle. Water was provided regularly.

The samples were acquired on a regular collection schedule using an artificial vagina and immediately transferred to the laboratory. Basic semen assessment was performed in each sample, including volume $(\mathrm{mL}), \mathrm{pH}$ and spermatozoa concentration $\left(\mathrm{x} 10^{6} / \mathrm{mL}\right)$.

Spermatozoa motility (MOT; percentage of motile spermatozoa; motility > 5 $\mu \mathrm{m} / \mathrm{s} ; \%$ ), progressive motility (PROG; percentage of progressive motile spermatozoa; motility $>20 \mu \mathrm{m} / \mathrm{s} ; \%$ ), distance average path (DAP, $\mu \mathrm{m}$ ), velocity average path (VAP, $\mu \mathrm{m} / \mathrm{s}$ ) and amplitude of lateral head displacement (ALH, $\mu \mathrm{m}$ ) were determined using the Computer Assisted Semen Analysis (CASA) system based on the SpermVision ${ }^{\mathrm{TM}}$ program (Minitube, Tiefenbach, Germany) and Olympus BX 51 phase contrast microscope (Olympus, Tokyo, Japan). The samples were placed into the Makler Counting Chamber (depth $10 \mu \mathrm{m}, 37^{\circ} \mathrm{C}$; Sefi Medical Instruments, Haifa, Israel) and assessed. At least 1000 cells were evaluated in each sample (Massányi et al., 2008).

The samples were centrifuged $\left(15 \mathrm{~min}, 10090 \times \mathrm{g}, 4^{\circ} \mathrm{C}\right)$, seminal plasma was transferred into $1.5 \mathrm{~mL}$ tubes and kept frozen $\left(-80^{\circ} \mathrm{C}\right)$. The cell sediments were moved into tubes containing $1.5 \mathrm{~mL}$ distilled water and subsequently lysed on ice using sonication $(28 \mathrm{kHz}, 30 \mathrm{sec})$. The lysates were centrifuged (15 min, 11828 $\times \mathrm{g}, 4{ }^{\circ} \mathrm{C}$ ) and the supernatants containing the intracellular content were transferred into $1.5 \mathrm{~mL}$ tubes and stored at $-80{ }^{\circ} \mathrm{C}$ until further analysis (Tvrdá et al., 2013a).

The assessment of TAS originates from the ability of all antioxidants in the sample to neutralize a prooxidant compound. The TAS Randox (Randox Laboratories, Crumlin, Great Britain) assay follows an incubation of ABTS (2,2' Azino-di-[3-ethylbenzthiazoline sulphonate]) with a peroxidase (metmyoglobin) and $\mathrm{H} 2 \mathrm{O} 2$ to produce the $\mathrm{ABTS}+$ radical. This has a relatively stable blue-green color, which may be measured at $600 \mathrm{~nm}$. Antioxidants present in the sample supress this color production to a degree, which is proportional to their concentration. TAS was assessed using the Genesys 10 spectrophotometer 
(Thermo Fisher Scientific Inc., Waltham, USA) and is expressed as $\mu \mathrm{mol} / \mathrm{mg}$ protein (Tvrda et al., 2012).

The FRAP assessment followed the original procedure described by Benzie and Strain (1996). It is a simple test to determine the total antioxidant power, based on the reduction of a ferric-tripyridyl triazine complex to its ferrous colored form in the presence of antioxidants. The FRAP reagent contains $10 \mathrm{mmol} / \mathrm{L}$ TPTZ ( 2 4 ,6- tripyridyl- s- triazine) solution in $40 \mathrm{mmol} / \mathrm{L} \mathrm{HCl}$ (Centralchem, Bratislava, Slovak Republic) plus $5 \mathrm{~mL}$ of $20 \mathrm{mmol} / \mathrm{L} \mathrm{FeCl} 3$ (Centralchem, Bratislava, Slovak Republic) and $50 \mathrm{~mL}$ of $0.3 \mathrm{~mol} / \mathrm{L}$ acetate buffer $(\mathrm{pH}=3.6$; Centralchem, Bratislava, Slovak Republic). Aliquots of $100 \mu \mathrm{L}$ sample were mixed with $3 \mathrm{~mL}$ FRAP reagent and the absorbance of reaction mixture was measured at $593 \mathrm{~nm}$ for 4 min using the Genesys 10 spectrophotometer (Thermo Fisher Scientific Inc., Waltham, USA) and is expressed as $\mathrm{mmol} / \mathrm{mg}$ protein.

Protein concentration was quantified using the DiaSys Total Protein (DiaSys, Holzheim, Germany) commercial kit, based on the Biuret method: copper sulphate reacts with proteins to create a violet blue color complex in alkaline solution, whose intensity is directly proportional to the protein content at $540 \mathrm{~nm}$ using a semi-automated clinical chemistry photometric analyzer Microlab 300 (Merck ${ }^{\circledR}$, Darmstadt, Germany) (Tvrdá et al., 2011).

All data were subjected to statistical analysis using the GraphPad Prism program (version 3.02 for Windows, GraphPad Software incorporated, San Diego, California, USA, http://www.graphpad.com/). Results are quoted as arithmetic mean \pm standard error (S.E.). Pearson product-moment correlation coefficient analysis for paired samples was used to assess correlations between all examined parameters. Additionally, the samples were categorized in three quality groups according to their motility rates. Comparative analysis of selected parameters in the seminal fractions as well as in the quality groups was carried out by one-way ANOVA with the Bonferroni multiple comparison test. The level of significance for the comparative as well as correlation analysis was set at ${ }^{* * * *}(\mathrm{P}<0.001)$ ${ }^{* *}(\mathrm{P}<0.01) ;{ }^{*}(\mathrm{P}<0.05)$

\section{RESULTS AND DISCUSSION}

Results from the seminal examination are shown in Table 1. Animal donors presented with no signs of disease or pathology. At the same time, the final values met the criteria established for the Simmental-Fleckvieh bovine breed, which is why a possible health impact on the outcomes from the biochemical assessment was ruled out.

\begin{tabular}{lc} 
Table 1 Basic seminal and motility characteristics of the samples $(\mathrm{n}=37)$ \\
\hline PARAMETER & Mean \pm S.E. \\
\hline Volume $[\mathrm{mL}]$ & $7.33 \pm 0.50$ \\
$\mathrm{pH}$ & $6.70 \pm 0.38$ \\
Concentration $\left[\times 10^{6}\right.$ cells $\left./ \mathrm{mL}\right]$ & $3005 \pm 51.91$ \\
Motility $[\%]$ & $87.36 \pm 4.55$ \\
Progressive motility $[\%]$ & $83.77 \pm 4.99$ \\
Distance average path $[\mu \mathrm{m}]$ & $35.19 \pm 4.05$ \\
Velocity average path $[\mu \mathrm{m} / \mathrm{s}]$ & $82.33 \pm 5.01$ \\
Amplitude of lateral head displacement $[\mu \mathrm{m}]$ & $4.76 \pm 0.29$ \\
\hline
\end{tabular}

Amplitude of lateral head displacement $[\mu \mathrm{m}]$

Results of the biochemical quantifications are presented in Table 2. Both antioxidant markers were higher in the seminal plasma when compared to the cell lysates $(\mathrm{P}<0.001$ with respect to TAS; $\mathrm{P}<0.01$ in case of FRAP).

Table 2 Antioxidant parameters of bovine seminal plasma and spermatozoa examined by UV/VIS spectrophotometry $(\mathrm{n}=37)$

\begin{tabular}{lcc}
\hline PARAMETER & $\begin{array}{c}\text { SEMINAL } \\
\text { PLASMA }\end{array}$ & $\begin{array}{c}\text { CELL } \\
\text { LYSATES }\end{array}$ \\
\hline $\begin{array}{l}\text { Total antioxidant status (TAS) } \\
\text { [mmol/mg prot] }\end{array}$ & $25.87 \pm 2.29$ & $48.22 \pm 4.23^{* * *}$ \\
$\begin{array}{l}\text { Ferric reducing ability of plasma } \\
\text { (FRAP) }[\mu \mathrm{mol} / \mathrm{g} \text { prot] }\end{array}$ & $151.05 \pm 9.56$ & $253.73 \pm 14.57^{* *}$ \\
\hline
\end{tabular}

Mean+S.E ${ }^{* * *}-\mathrm{P}<0.001$

Table 3 displays the results of the correlation analysis between the motility characteristics, and antioxidant characteristics assessed in bovine seminal plasma and spermatozoa. All spermatozoa motion parameters were significantly $(\mathrm{P}<0.01)$ positively correlated with both TAS and FRAP.

Table 3 Correlations between the spermatozoa motility parameters and antioxidant capacity in bovine seminal plasma and cell lysates evaluated by the Pearson's correlation coefficient test $(n=37)$

\begin{tabular}{|c|c|c|c|c|c|c|c|c|c|}
\hline & MOT & PROG & DAP & VAP & ALH & TAS [SP] & FRAP [SP] & TAS [CL] & FRAP $[$ CL] \\
\hline MOT & 1 & & & & & & & & \\
\hline PROG & $0.972^{* * * *}$ & 1 & & & & & & & \\
\hline DAP & $0.950^{* * *}$ & $0.959^{* * *}$ & 1 & & & & & & \\
\hline VAP & $0.935^{\text {*** }}$ & $0.937^{* * *}$ & $0.936^{\text {*** }}$ & 1 & & & & & \\
\hline ALH & $0.933^{\text {*** }}$ & $0.935^{\text {*** }}$ & $0.938^{* * * *}$ & $0.945^{* * *}$ & 1 & & & & \\
\hline TAS [SP] & $0.460^{* *}$ & $0.478^{* *}$ & $0.444^{* *}$ & $0.449^{* *}$ & $0.450^{* *}$ & 1 & & & \\
\hline FRAP [SP] & $0.422^{* *}$ & $0.433^{* *}$ & $0.412^{* *}$ & $0.410^{* *}$ & $0.411^{* *}$ & $0.451^{* *}$ & 1 & & \\
\hline TAS $[$ CL] & $0.468^{* *}$ & $0.485^{\text {** }}$ & $0.449^{* *}$ & $0.453^{\text {** }}$ & $0.459^{* *}$ & $0.779^{* * *}$ & $0.337^{*}$ & 1 & \\
\hline FRAP $[C L]$ & $0.452^{* *}$ & $0.444^{* *}$ & $0.417^{* *}$ & $0.421^{* *}$ & $0.418^{* * *}$ & $0.343^{*}$ & $0.758^{* * * *}$ & $0.501^{* *}$ & 1 \\
\hline
\end{tabular}

The correlation analysis was based on the value of the correlation coefficient: $\pm 0.111- \pm 0.333$ : low correlation; $\pm 0.334- \pm 0.666$ : moderate correlation; \pm 0.667 \pm 0.999 : high correlation. ${ }^{*}-\mathrm{P}<0.05 ;{ }^{* *}-\mathrm{P}<0.01 ;{ }^{* * *}$ - $\mathrm{P}<0.001$. MOT - spermatozoa motility [\%], PROG - spermatozoa progressive motility [\%], DAP - distance average path $[\mu \mathrm{m}], \mathrm{VAP}$ - velocity average path $[\mu \mathrm{m} / \mathrm{s}]$, ALH - amplitude of lateral head displacement $[\mu \mathrm{m}]$, TAS - total antioxidant status $[\mathrm{mmol} / \mathrm{mg}$ of protein], FRAP - ferric reducing ability of plasma $[\mu \mathrm{mol} / \mathrm{g}$ of protein]. SP - seminal plasma, CL - cell lysates.

To have a better understanding of the results, the samples were categorized in three groups of excellent ( $\mathrm{Ex} ;>90 \%$ motile; $\mathrm{n}=13$ ), good (Go; 80-90\% motile $\mathrm{n}=14$ ) and moderate $(\mathrm{Mo} ;<80 \%$ motile; $\mathrm{n}=10)$ quality according to their motility rates (Table 4). Mean values for MOT, PROG, DAP, VAP as well as ALH were significantly different between the groups $(\mathrm{P}<0.001 \mathrm{Ex}$ vs. Go and Ex vs. Mo)
The highest TAS and FRAP concentrations were recorded in the Ex group of both seminal fractions. Inversely, the lowest antioxidant activity was detected in the Mo group. Significant differences $(\mathrm{P}<0.01)$ were observed when comparing the antioxidant parameters between the Ex and the Mo groups.

Table 4 Average values of seminal motility parameters and antioxidant capacity in the quality groups (Mean \pm S.E.) and Bonferroni multiple comparison test results $(\mathrm{n}=37)$

\begin{tabular}{|c|c|c|c|}
\hline PARAMETER & $\operatorname{Ex}(n=13)$ & Go $(n=14)$ & $\operatorname{Mo}(n=10)$ \\
\hline MOT [\%] & $93.99 \pm 0.59$ & $85.64 \pm 0.87^{* a}$ & $63.22 \pm 0.65^{* * * b, *^{* * *} \mathrm{c}}$ \\
\hline PROG [\%] & $89.67 \pm 0.62$ & $79.51 \pm 1.33^{* a}$ & $56.94 \pm 2.01^{* * * \mathrm{~b},{ }^{* * * *} \mathrm{c}}$ \\
\hline $\mathrm{DAP}[\mu \mathrm{m}]$ & $42.12 \pm 1.57$ & $36.22 \pm 2.05^{* \mathrm{a}}$ & $22.31 \pm 2.12^{* * * \mathrm{~b},{ }^{* * * *_{\mathrm{c}}}}$ \\
\hline $\mathrm{VAP}[\mu \mathrm{m} / \mathrm{s}]$ & $90.16 \pm 2.22$ & $80.34 \pm 1.91^{* a}$ & 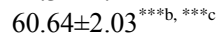 \\
\hline ALH $[\mu \mathrm{m}]$ & $5.35 \pm 0.12$ & $4.22 \pm 0.44^{* a}$ & $2.29 \pm 0.19^{* * * \mathrm{~b}, * * * \mathrm{c}}$ \\
\hline TAS [SP] [mmol/mg prot] & $30.11 \pm 3.02$ & $26.22 \pm 3.10$ & $19.23 \pm 2.22^{* * \mathrm{~b}}$ \\
\hline FRAP $[\mathrm{SP}][\mu \mathrm{mol} / \mathrm{g}$ prot $]$ & $189.47 \pm 3.99$ & $145.11 \pm 5.02^{* a}$ & $120.65 \pm 9.55^{* * \mathrm{~b},{ }^{*} \mathrm{c}}$ \\
\hline TAS [CL] [mmol/mg prot] & $56.09 \pm 3.02$ & $49.13 \pm 2.98$ & $40.04 \pm 2.11^{* * \mathrm{~b}}$ \\
\hline FRAP $[C L][\mu \mathrm{mol} / \mathrm{g}$ prot $]$ & $277.09 \pm 9.87$ & $255.18 \pm 8.67$ & $228.33 \pm 5.55^{* * \mathrm{~b}}$ \\
\hline
\end{tabular}

Although conventional semen indicators may meet the conditions of applicability for artificial insemination, traditional assessment of semen immediately after collection may not completely capture the overall spermatozoa fertility, as shown by differences e.g. in spermatozoa viability assessment (Colebrandner $\boldsymbol{e t} \boldsymbol{a l}$., 2003; Härtlová et al., 2013). The reason may lie in changes of biochemical properties of seminal plasma or spermatozoa (Podstawski et al., 2007). 
The seminal plasma is the central reservoir of antioxidants protecting the ejaculate against oxidative damage (Agarwal $\boldsymbol{e t}$ al., 2006). Our records agree showing that the TAS as well as FRAP, both techniques routinely used to assess the antioxidant capacity of the sample, were significantly higher (Table 2) in the seminal plasma, suggesting that this semen fraction may be protected by a complex antioxidant system (Selley et al., 1991).

It has been reported on different occasions that a proper ROS detoxification, thus the balance between individual components of the antioxidant system in semen is important to maintain the spermatozoa motility (Khosrowbeygi et al., 2004; Eghbali et al., 2008; Tvrda et al., 2013a,b). Positive correlations between enzymatic or non-enzymatic antioxidants and sperm motility have been related to lower oxidative insults and cytotoxicity to spermatozoa. Measurements of antioxidant components and characteristics have also shown significan differences between case and control groups and correlated with sperm motility (Khosrowbeygi et al., 2004; Pahune et al., 2013).

One advantage of our study was centrifugation of semen samples at high speed to precisely separate the seminal plasma from spermatozoa, as the membrane-bound oxidases or antioxidants associated with cellular debris and/or organelles may have an impact on the seminal plasma antioxidants (Zini et al., 2000), and vice versa, as seen in the correlation analysis (Table 3 ).

Diverse techniques have been developed to assess the antioxidant capacity of a variety of molecules, nevertheless as many variables are taken into account when focusing on the antioxidant properties of a complex sample, the outcomes have to be treated cautiously (Alam $\boldsymbol{e t}$ al., 2002). There is no universal system able to provide information about the 'true' antioxidant power of a single antioxidant or a complex mixture of antioxidant substances. At the same time, a comparative evaluation of antioxidant capacity is difficult to perform as the activity depends on the substrate, reaction medium, oxidation conditions, interfacial phenomena or the antioxidant partitioning properties between separate phases (Litescu $\boldsymbol{e t}$ al. 2010). Here we used two very frequently applied methods to estimate the antioxidant capacity of the seminal plasma and lysates.

While the FRAP assay is based on reduction of a ferric-tripyridyl triazine complex to its ferrous colored form in the presence of antioxidants, the TAS is an ABTS related decolorization assay. Although the principles of the assays may be different, both are based on assessing the capacity of all the hydrophilic as well as lipophilic molecules able to metabolize ROS. Independently of the assay applied, the total antioxidant capacity has been found to be associated with semen quality along with sperm viability and functional activity (Khosrowbeygi $\boldsymbol{e t}$ al. 2004; Tvrda et al., 2012; Pahune et al., 2013). Furthermore, positive correlations between the parameters in both seminal fractions (Table 3), as well as similar associations between the spermatozoa motility characteristics and biochemical markers (Table 4) suggest that both assays are suitable for the measurement of the in vivo antioxidant status of semen.

\section{CONCLUSION}

This study sheds more light on the complexity of interactions between semen quality and antioxidant profile of bovine ejaculates. At the same time our results indicate that both methodologies used to assess the antioxidant capacity of biological material are equally suitable to be used in veterinary andrology. Lastly, we recommend that routine evaluation of the seminal antioxidant capacity should be considered during male fertility assessment in animal production.

Acknowledgments: This study was supported by the Slovak Research and Development Agency grant no. APVV-0304-12.

\section{REFERENCES}

Agarwal, A., Gupta, S. \& Sikka, S. (2006). The role of free radicals and antioxidants in reproduction. Current Opinion in Obstetrics and Gynecology, 18 , 325-332. http://dx.doi.org/10.1097/01.gco.0000193003.58158.4e.

Agarwal, A., Prabakaran, S.A. \& Sikka, S.C. (2007). Clinical relevance of oxidative stress in patients with male factor infertility: evidence-based analysis. AUA Update Series, 26, 1-12.

Aitken, R.J. (1995). Free radicals, lipid peroxidation and sperm function. Reproduction, Fertility and Development, 7, 659-668.

Alam, M.N., Bristi, N.J. \& Rafiquzzaman, M. (2013). Review on in vivo and in vitro methods evaluation of antioxidant activity. Saudi Pharmaceutical Journal, 21(2), 143-152. http://dx.doi.org/10.1016/j.jsps.2012.05.002.

Apak, R., Gorinstein, S., Böhm, V., Schaich, K.M., Özyürek, M. \& Güçlü, K. (2013). Methods of measurement and evaluation of natural antioxidan capacity/activity. Pure and Applied Chemistry, 85, 957-998. http://dx.doi.org/10.1351/PAC-REP-12-07-15.

Armstrong, J.S., Rajasekaran, M., Chamulitrat, W., Gatti, P., Hellstrom, W.J. \& Sikka, S.C. (1999). Characterization of reactive oxygen species induced effects on human spermatozoa movement and energy metabolism. Free Radical Biology and Medicine, 26, 869-880.

Badarinath, A.V., Rao, K.M., Chetty, C.M.S., Ramkanth, V., Rajan, T.V.S. \& Gnanaprakash, K. (2010). A review on in vitro antioxidant methods comparisons, correlations and considerations. International Journal of PharmTech Research, 2(2), 12.

Benzie, I.F. \& Strain, J.J. (1996). The ferric reducing ability of plasma (FRAP) as a measure of "antioxidant power": the FRAP assay. Annals of Biocehmistry, 239 (1), 70-76.

Colenbrander, B., Gadella, B.M. \& Stout, T.A. (2003). The predictive value of semen analysis in the evaluation of stallion fertility. Reproduction in Domestic Animals, 38, 2003, 305-311.

Eghbali, M., Alavi-Shoushtari, S.M. \& Asri Rezaii, S. (2008). Effects of copper and superoxide dismutase content of seminal plasma on buffalo semen characteristics. Pakistan Journal of Biological Sciences, 11 (15), 1964-1968 http://dx.doi.org/10.3923/pjbs.2008.1964.1968.

Eskenazi, B., Wyrobek, A.J., Sloter, E., Kidd, s.A., Young, S. \& Moore, D. (2003). The association of age and semen quality in healthy men. Human Reproduction, 18, 447-454.

Härtlová, H., Rajmon, R., Krontorádová, I., Mamica, J., Zita, L., Klabanová, P. \& Černocký, A. (2013). Semen quality, lipid peroxidation, and seminal plasma antioxidant status in horses with different intensities of physical exercise. Acta Veterinaria Brno, 82, 31-35. http://dx.doi.org/10.2754/avb201382010031.

Khosrowbeygi, A., Zarghami, N. \& Deldar, Y. (2004). Correlation between sperm quality parameters and seminal plasma antioxidants status. Iranian Journal of Reproductive Medicine, 2 (2), 58-64.

Litescu, S.C., Eremia, S. \& Radu, G.L. (2010). Methods for the determination of antioxidant capacity in food and raw materials. In: Giardi, M.T., Rea, G. \& Berra B. (2010). Bio-Farms for Nutraceuticals. Austin: Landes Bioscience and Springer Science+Business Media.

Massányi, P., Chrenek, P., Lukáč, N., Makarevich, A.V., Ostro, A., Živčak, J. \& Bulla, J. (2008). Comparison of different evaluation chambers for analysis of rabbit spermatozoa motility using CASA system. Slovak Journal of Animal Science, 41, 60-66.

Pahune, P.P., Choudhari, A.R. \& Muley, P.A. (2013). The total antioxidant power of semen and its correlation with the fertility potential of human male subjects. Journal of Clinical and Diagnostic Research, 7(6), 991-995. http://dx.doi.org/10.7860/JCDR/2013/4974.3040.

Podstawski, Z., Kosiniak-Kamysz, K. \& Bittmar, A. (2007). Relationship between some enzymes activity, morphology and stallion semen quality. Zootehnie si Biotehnologii, 40, 152-156.

Selley, M.L., Lacey, M.J., Bartlett, M.R., Copeland, C.M. \& Ardlie, N.G. (1991) Content of significant amounts of a cytotoxic end-product of lipid peroxidation in human semen. Journal of Reproduction and Fertility, 92 (2), 291-298.

Sikka, S.C., Rajasekaran, M. \& Hellstrom, W.J. (1995). Role of oxidative stress and antioxidants in male infertility. Journal of Andrology, 16, 464-468.

Tvrdá, E., Kňažická, Z., Massáyni, P. \& Lukáč, N. (2011). Relationships between levels of nitrogen compounds with antioxidant properties and semen quality in bulls. Contemporary Agriculture, 60 (3-4), 244-252.

Tvrda, E., Knazicka, Z. \& Lukac, N. (2012). Selected heavy metals versus antioxidant parameters in bull seminal plasma - a comparative study. Journal of Environmental Science and Health A, 47 (9), 1261-1266. http://dx.doi.org/10.1080/10934529.2015.1071153.

Tvrdá, E., Kňažická, Z., Lukáčová, J., Schneidgenová, M., Goc, Z., Greń, A. Szabó, C., Massányi, P. \& Lukáč, N. (2013a). The impact of lead and cadmium on selected motility, prooxidant and antioxidant parameters of bovine seminal plasma and spermatozoa. Journal of Environmental Science and Health A, 48 (10), 1292-1300. http://dx.doi.org/10.1080/10934529.2013.777243.

Tvrdá, E., Lukáč, N., Schneidgenová, M., Lukáčová, J., Szabó, C., Goc, Z., Greń, A. \& Massányi, P. (2013b). Impact of seminal chemical elements on the oxidative balance in bovine seminal plasma and spermatozoa. Journal of Veterinary Medicine, 2013, 1-8. http://dx.doi.org/ 10.1155/2013/125096.

Zini, A., Garrels, K. \& Phang, D. (2000). Antioxidant activity in the semen of fertile and infertile men. Urology, 55, 922-926. 